Article

\title{
Iron Isotopes Constrain the Metal Sources of Skarn Deposits: A Case Study from the Han-Xing Fe Deposit, China
}

\author{
Bin Zhu ${ }^{1,2, *}$, Hongfu Zhang ${ }^{2}$, M. Santosh ${ }^{3,4}$, Benxun Su ${ }^{2,5}$, Pengfei Zhang ${ }^{6}$, Chunming Han ${ }^{2}$ \\ and Yongsheng $\mathrm{He}^{7}$ \\ 1 Beijing Research Institute of Uranium Geology, Beijing 100029, China \\ 2 State Key Laboratory of Lithospheric Evolution, Institute of Geology and Geophysics, \\ Chinese Academy of Sciences, Beijing 100029, China; hfzhang@mail.igcas.ac.cn (H.Z.); \\ subenxun@mail.igcas.ac.cn (B.S.); Cm-han@mail.iggcas.ac.cn (C.H.) \\ 3 School of Earth Sciences and Resources, China University of Geosciences, Beijing 100083, China; \\ msantosh.gr@gmail.com \\ 4 Centre for Tectonics, Resources and Exploration, Department of Earth Sciences, University of Adelaide, \\ Adelaide, SA 5005, Australia \\ 5 University of Chinese Academy of Sciences, Beijing 100049, China \\ 6 Department of Earth Science, The University of Hong Kong, Hong Kong, China; \\ zhangpengfei073061@163.com \\ 7 State Key Laboratory of Geological Processes and Mineral Resources, China University of Geosciences, \\ Beijing 100083, China; heys@cugb.edu.cn \\ * Correspondence: zhubin2016@126.com
}

Received: 10 August 2020; Accepted: 29 September 2020; Published: 26 October 2020

\begin{abstract}
Magmatic fluids and leaching of rocks are regarded as the two sources of magmatic hydrothermal deposits, but their relative contributions to the metals in the deposits are still unclear. In this study, we combine major elements and Fe isotopes in two sets of rocks from the Han-Xing iron skarn deposit in China to constrain the iron sources. The positive correlation between the $\delta^{56} \mathrm{Fe}$ and $\sum \mathrm{Fe}_{2} \mathrm{O}_{3} / \mathrm{TiO}_{2}$ of altered diorites $\left(\sum \mathrm{Fe}_{2} \mathrm{O}_{3}\right.$ refers to the total iron) demonstrates that heavy $\mathrm{Fe}$ isotopes are preferentially leached from diorites during hydrothermal alteration. However, except for the pyrite, all the rocks and minerals formed in the skarn deposit are enriched in the light Fe isotope relative to the fresh/less altered diorites. Therefore, besides the leaching of rocks, the Fe isotopically light magmatic fluid also provides a large quantity of iron for this deposit. Based on the mass balance calculation, we conclude that iron from magmatic fluid is almost 2.6 times as large as that from the leaching of rocks. This is the first study to estimate the relative proportions of iron sources for Fe deposits by using Fe isotopes. Here, we propose that the high $\delta^{56} \mathrm{Fe}$ of magmatic intrusions combining the positive correlation between their $\sum \mathrm{Fe}_{2} \mathrm{O}_{3} / \mathrm{TiO}_{2}$ and $\delta^{56} \mathrm{Fe}$ could be taken as a fingerprint of exsolution or interaction with magmatic fluids, which contributes to the exploration of magmatic hydrothermal ore deposits.
\end{abstract}

Keywords: Han-Xing iron deposit; iron isotopes; metal source; isotope fractionation; mass balance

\section{Introduction}

One of the main prerequisites for the genetic modeling and exploration strategies of metallic mineral deposits is the understanding of their metal source and the mechanism of concentration. Magmatic hydrothermal ore deposits are the most common metalliferous ore deposits and provide much of the $\mathrm{Cu}, \mathrm{Mo}, \mathrm{Au}, \mathrm{W}$ and Fe for the needs of modern society [1]. However, there is still 
controversy over the metal sources of magmatic hydrothermal ore deposits, e.g., [2,3]. As early as the 1960s, light stable isotopes (e.g., H, C, O, N and S) had been used to constrain the origin of fluids in hydrothermal ore deposits, e.g., [4-8]. Since these elements are not ore-forming elements, it is difficult to decipher the metal source based on their isotopic compositions. For example, $\mathrm{H}$ and O isotopes of hydrothermal minerals and fluid inclusions in skarn deposits often display mixing between magmatic and meteoric water, whereas $S$ isotopes often show the dominance of magmatic sulfur with minor sedimentary sulfur [9]. Therefore, none of these isotopes can provide direct and explicit information about the metal source. The emerging field of metal stable isotopes (e.g., Fe, $\mathrm{Cu}, \mathrm{Mg}, \mathrm{Mo}, \mathrm{Zn}$ and $\mathrm{Cr}$ ) provides a potential tool to constrain the metal sources directly through the application of isotopes of ore-forming elements, e.g., [10-12].

Metals leached from rocks on the fluid pathway have been regarded as the main metal sources of hydrothermal ore deposits, e.g., [13-15]. This viewpoint is well consistent with the field geological observation, which shows that altered wall rocks near the ore bodies commonly lack ore-forming elements. Moreover, many studies of $\mathrm{H}$ and $\mathrm{O}$ isotopes of hydrothermal minerals and fluid inclusions indicate that both magmatic water and meteoric water play important roles in a variety of types of hydrothermal ore deposits, e.g., [6,16], and chemical dissolution of rocks will be enhanced in the hot and acidic ore-forming fluid [2]. Therefore, a large school of thought emphasizes that metals can be largely scavenged from pre-existing rocks and enter into ore-forming fluid to form ore deposits, e.g., $[13,14]$. However, experimental studies have led to a different point of view that the extraction of metals from the silicate magma into magmatic fluids is a key stage in the evolution of the mineralized hydrothermal system [3], implying that magmatic fluids are the primary source of the major components in hydrothermal ore deposits. However, the extent to which magmas contribute water, metals and other components to hydrothermal systems remains debated [2].

The Han-Xing iron deposit is a typical iron skarn deposit in China and has been well documented by numerous studies, e.g., $[15,17,18]$. Albitization is extensively developed in the associated intrusive rock near the ore bodies and iron leaches from the wall rocks during this process [15]. Thus, the Han-Xing iron deposit is an ideal example to study iron isotope fractionation during leaching and to constrain the source of its iron. Based on the study of the Kuangshan (Wu'an district) skarn deposit, the authors found a large iron isotope fractionation during the skarn-type alteration and proposed that magmatic fluids might dominate the iron source of the Han-Xing iron deposits [12]. It is worth to note that the lithology of intrusive rocks in the Han-Xing iron skarn ore cluster is diverse (ranging from the intermediate-basic hornblende diorite to the intermediate-acidic quartz diorite). Whether these rocks have the same fractionation features during the skarn-type alteration is still unknown. In addition, more iron isotopic data are needed to calculate the relative contributions of the iron leached from the rock and that from the magmatic fluid. In this study, we analyzed two sets of rocks (different intrusive rocks) from the Han-Xing iron skarn ore cluster for their major elements and Fe isotopes to understand iron isotope fractionation and to evaluate the relative proportion of the two metal sources mentioned above. Each set includes intrusive rocks, skarn, ores and limestone, to cover a whole spectrum of rock types for skarn deposits.

\section{Geological Setting}

The Han-Xing iron skarn ore cluster is located in the central part of the North China Craton (NCC) (Figure 1A). The basement rocks in this region are mainly composed of tonalite-trondhjemite-granodiorite (TTG) gneisses and amphibolites, whose protoliths were formed during the Meso-Neoarchean and were metamorphosed during the late Paleoproterozoic coeval with the final cratonization of the NCC [19]. Regionally, the sedimentary rocks in this area are dominated by Cambrian-Ordovician carbonates in the western part and Carboniferous-Permian clastic rocks in the eastern part (Figure 1B). Mesozoic magmatic rocks intruded into the Precambrian basement as well as the sedimentary cover. Previous studies proposed that the source magmas of these 
intermediate intrusive rocks were generated by crust-mantle interactions with zircon SHRIMP U-Pb ages of 126-138 Ma [20].

The Han-Xing Fe ore cluster consists of 73 iron skarn deposits with a total reserve of $830 \mathrm{Mt}$ tons of metallic iron (average $40 \%$ to $60 \%$ ) [21]. It has been widely accepted as the product of contact metamorphism between Mesozoic plutons and surrounding Ordovician carbonate sedimentary strata [18]. The associated intrusive suites can be divided into two groups: Fushan gabbroic diorite in the west and $\mathrm{Wu}^{\prime}$ an diorite-monzonite in the east (Figure 1B). The two sets of rocks analyzed in this study are collected from the two districts. Rocks from Fushan are outcrop samples, while rocks from Baijian (Wu'an district) are drill core samples.
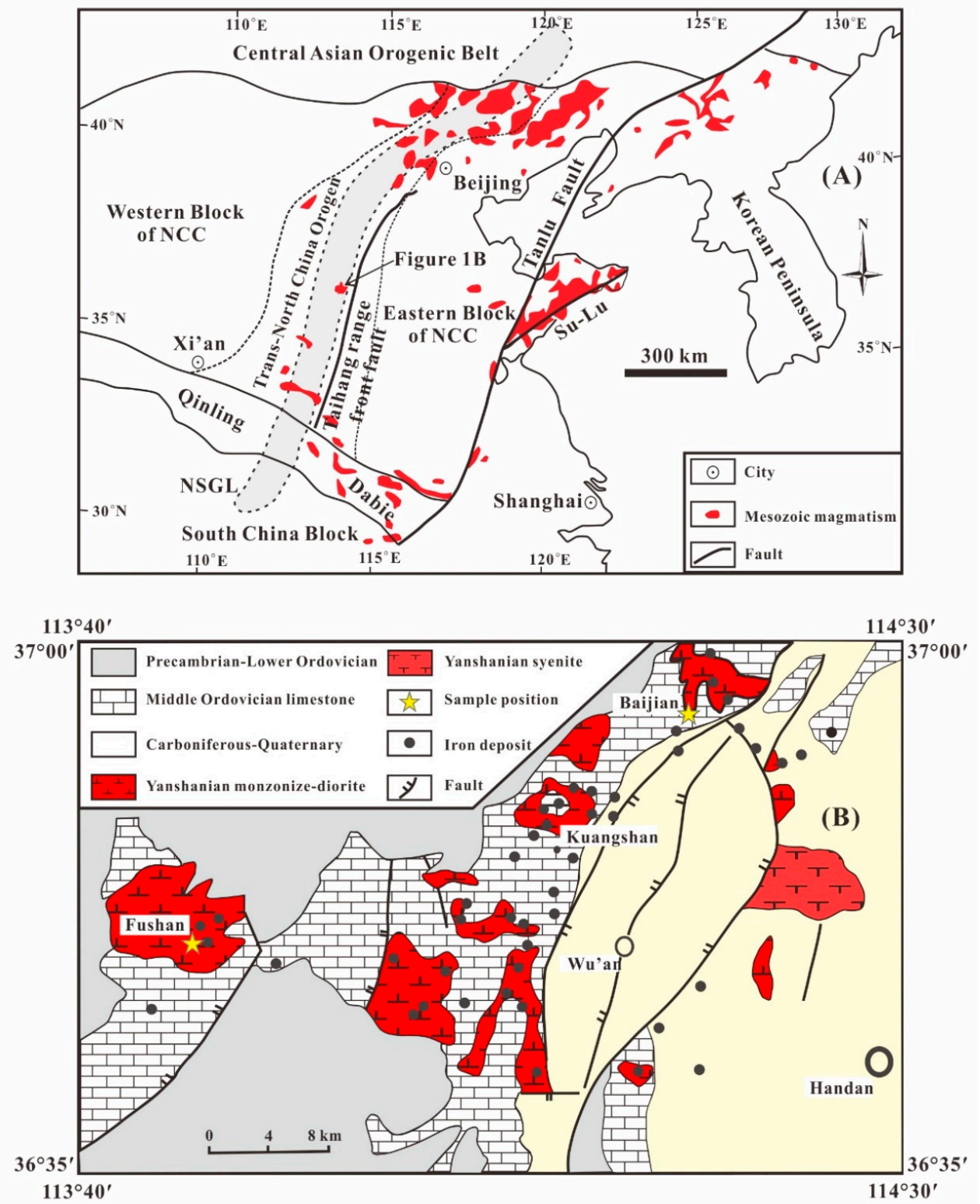

Figure 1. (A) Simplified geological map showing major tectonic subdivisions of the North China Craton (NCC) with emphasis on the distribution of Mesozoic magmatic rocks (after the references [22,23]). (B) Local geological map of the Han-Xing Fe skarn deposit (modified from the reference [18]). 


\section{Samples and Methods}

The Fushan intrusive complex consists of hornblende diorite, diorite and quartz diorite and the $\mathrm{Wu}^{\prime}$ an intrusive complex consists of monzodiorite and diorite (detailed descriptions of mineral composition are given in Table 1). Petrological observations indicate that most of these intrusive rocks (hereafter collectively referred to as "diorite") underwent various degrees of hydrothermal alteration. In slightly altered diorites, hornblende was transformed into aggregates of diopside, biotite, albite and magnetite (Figure 2C,E). With the increase in intensity of hydrothermal alteration, the newly formed diopside and biotite were further transformed to albite or epidote accompanied by the dissolution of magnetite. Almost no magnetite remains in intensively altered diorites (Figure 2B,D,F). The skarn assemblage is mainly composed of garnet, diopside and epidote with taxitic and massive structures. Ores are composed of magnetite, skarn minerals and minor sulfides with dense disseminated, taxitic and massive structures. Magnetite in ores occurs as anhedral fine grains or euhedral medium to coarse grains. Sulfides are anhedral to euhedral fine to medium grains and predominantly occur between the magnetite and gangue minerals (dominance of diopside and epidote), suggesting that they formed after the magnetite and gangue minerals.

Table 1. Sample description of typical hand specimens of altered diorites, skarn and ores from the Han-Xing iron deposit.

\begin{tabular}{|c|c|c|}
\hline Type & Sample & Description \\
\hline \multirow{8}{*}{$\begin{array}{l}\text { Igneous } \\
\text { Rock }\end{array}$} & FS12-01 & $\begin{array}{l}\text { Fresh to less altered quartz diorite consists of medium-grained, black-green amphibole } \\
\qquad(10 \%) \text {, plagioclase }(75 \%) \text {, quartz }(10 \%) \text { and K-feldspar }(5 \%) \text {. }\end{array}$ \\
\hline & FS12-02 & $\begin{array}{l}\text { Altered quartz diorite consists of medium-grained, green amphibole (5\%), plagioclase } \\
\qquad(75 \%), \mathrm{K} \text {-feldspar }(10 \%) \text { and quartz }(10 \%) .\end{array}$ \\
\hline & FS12-03 & $\begin{array}{l}\text { Less altered diorite consists of medium-grained, euhedral black-green amphibole }(20 \%) \text {, } \\
\text { biotite }(5 \%) \text { and plagioclase }(70 \%) \text { with K-feldspar and quartz less than } 5 \% .\end{array}$ \\
\hline & FS12-04 & $\begin{array}{l}\text { Altered diorite consists of medium-grained, green amphibole }(15 \%) \text {, biotite }(3 \%) \text { and } \\
\text { plagioclase }(75 \%) \text { with K-feldspar and quartz less than } 7 \% \text {. }\end{array}$ \\
\hline & FS12-05 & $\begin{array}{c}\text { Fresh hornblende diorite consists of coarse-grained, euhedral black-green amphibole }(40 \%) \\
\text { and plagioclase }(55 \%) \text { with pyroxene and quartz less than } 5 \% \text {. }\end{array}$ \\
\hline & BJ0818-21 & $\begin{array}{l}\text { Intensively altered monzodiorite with porphyritic-like texture, consists of plagioclase } \\
\qquad(80 \%) \text { and K-feldspar }(10 \%) \text { with quartz and pyroxene less } 10 \% \text {. }\end{array}$ \\
\hline & BJ0818-23 & $\begin{array}{c}\text { Less altered monzodiorite with equigranular texture, consists of medium-grained, } \\
\text { euhedral black-green amphibole (20\%) and plagioclase (75\%) with K-feldspar and quartz } \\
\text { less than } 5 \% .\end{array}$ \\
\hline & BJ0818-27 & $\begin{array}{c}\text { Most intensively altered monzodiorite with porphyritic-like texture, close to the skarn; } \\
\text { consists of coarse-grained yellow-green epidote }(10 \%) \text { and plagioclase }(80 \%) \text { with quartz } \\
\text { and pyroxene less than } 10 \% \text {. }\end{array}$ \\
\hline \multirow{4}{*}{ Skarn } & FS12-08 & $\begin{array}{l}\text { Skarn with taxitic structure mainly consists of coarse-grained garnet }(80 \%) \text { and } \\
\text { fined-grained diopside }(15 \%) \text { with quartz and calcite less than } 5 \% \text {. }\end{array}$ \\
\hline & FS12-09 & $\begin{array}{c}\text { Skarn with taxitic to massive structure mainly consists of medium-grained diopside }(85 \%) \\
\text { and coarse-grained garnet }(10 \%) \text { with quartz and calcite less than } 5 \% \text {. }\end{array}$ \\
\hline & BJ0818-28 & $\begin{array}{c}\text { Skarn with taxitic to massive structure mainly consists of medium-grained epidote }(80 \%) \\
\text { and diopside }(10 \%) \text { with quartz and calcite less than } 10 \% \text {. }\end{array}$ \\
\hline & BJ0818-30 & $\begin{array}{l}\text { Skarn with taxitic structure mainly consists of medium-grained epidote }(70 \%) \text { and garnet } \\
\qquad(20 \%) \text { with biotite, quartz and calcite less than } 10 \% \text {. }\end{array}$ \\
\hline \multirow{3}{*}{ Ores } & FS12-13 & $\begin{array}{l}\text { Medium-fine-grained ore with dense disseminated structure, contains } 45 \% \text { magnetite; } \\
\text { gangue minerals consist of diopside, garnet, epidote, calcite and minor sulfides. }\end{array}$ \\
\hline & FS12-17 & $\begin{array}{l}\text { Medium-fine-grained ore with massive structure, contains } 80 \% \text { magnetite; gangue } \\
\text { minerals consist of diopside, garnet, epidote, calcite and minor sulfides. }\end{array}$ \\
\hline & BJ0818-36 & $\begin{array}{l}\text { Fine-grained ore with taxitic-massive structure, contains } 60 \% \text { magnetite; gangue minerals } \\
\text { consist of epidote, diopside, calcite and minor sulfides. }\end{array}$ \\
\hline
\end{tabular}



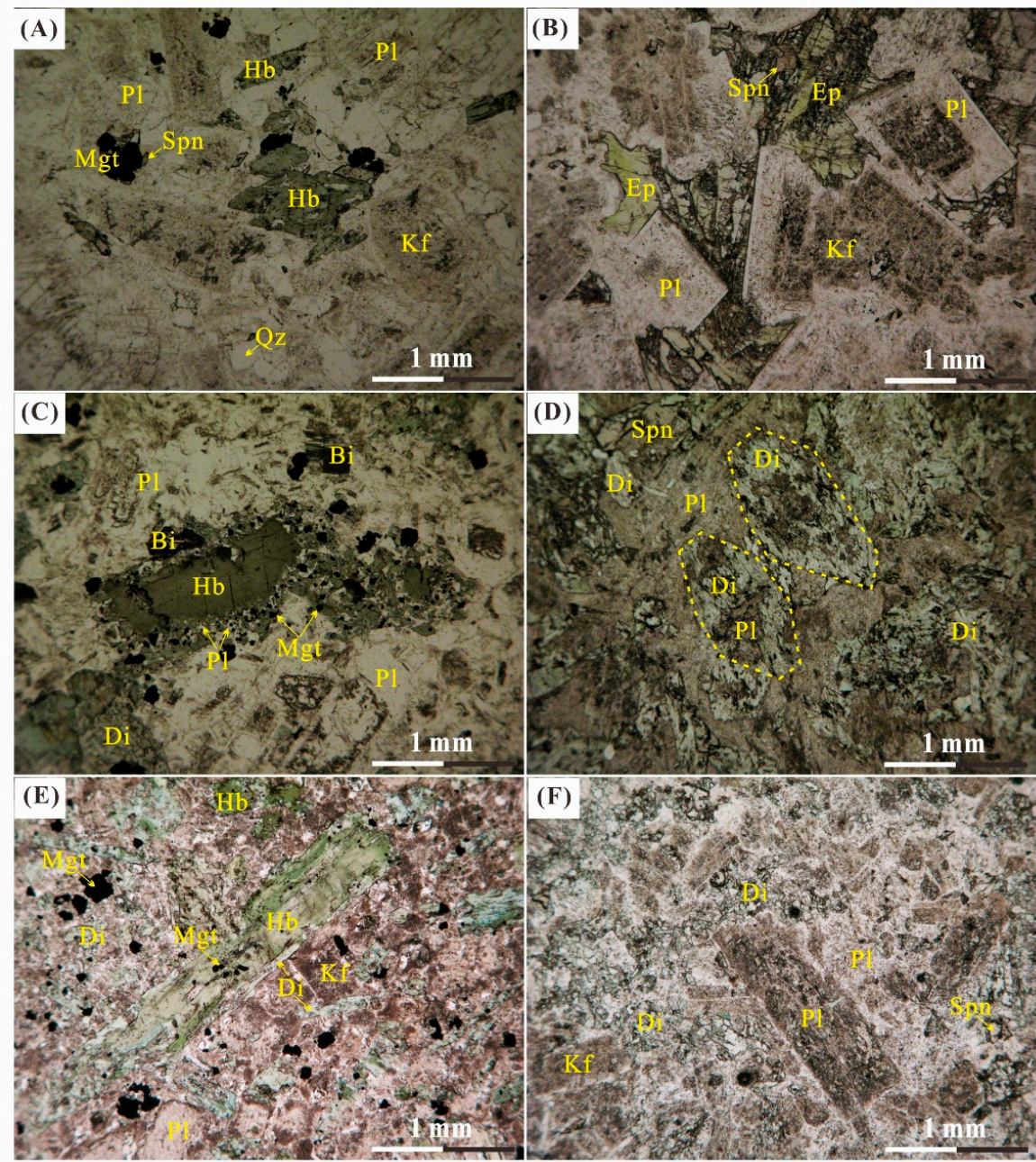

Figure 2. Microphotographs in transmitted light illustrate the characteristics of altered plutonic rocks from the Han-Xing iron deposit. (A) Fresh quartz diorite (FS-01) with medium-grained equigranular texture; it is characterized by fresh euhedral hornblende. (B) Intensively altered quartz diorite (FS-02); hornblende has been replaced by epidote without magnetite residual. (C) Less altered diorite (FS-03); at the edge of hornblende, it has been altered to the aggregates of diopside, albite, magnetite and biotite. (D) Intensively altered diorite (FS-04); euhedral hornblende has been totally replaced by the diopside remaining with its previous morphology. (E) Less altered monzodiorite (BJ0818-23); hornblende has been altered to the diopside and magnetite. (F) Intensively altered monzodiorite (BJ0818-21); hornblende and magnetite have been dissolved from the monzodiorite, leaving the plagioclase and diopside as residuals. Abbreviations: $\mathrm{Hb}$-hornblende; $\mathrm{Di}$-diopside; $\mathrm{Bi}$-biotite; Ep-epidote; $\mathrm{Pl}$-Plagioclase; Kf-K-feldspar; Qz-quartz; Spn—sphene; Mgt—magnetite.

Whole rocks were powdered with an agate mill to 200 mesh and $0.5 \mathrm{~g}$ powders were mixed with $5 \mathrm{~g}$ of $\mathrm{Li}_{2} \mathrm{~B}_{4} \mathrm{O}_{7}$. A glass slice was prepared via fusion. Major elements were determined using a Phillips PW 2400 sequential X-ray fluorescence spectrometer at the Institute of Geology and Geophysics, Chinese Academy of Sciences (Beijing, China). The analytical precision and the accuracy are better than $\pm 2 \%$ for major oxides. Loss on ignition was measured after heating to $1000{ }^{\circ} \mathrm{C}$ for $1.5 \mathrm{~h}$. The FeO was determined by redox titration using $\mathrm{KMnO}_{4}$ solution and the analytical precision is estimated to be $<1 \%$.

The chemical purification of iron was achieved in the Isotope Geochemistry Lab, China University of Geosciences, Beijing (CUGB). Typically, 2-30 mg whole rock powders or mineral separates were dissolved in a mixture of $\mathrm{HF}_{-} \mathrm{HNO}_{3}-\mathrm{HCl}-\mathrm{HClO}_{4}$. After complete dissolution, iron was purified using 
the AG1-X8 (200-400 mesh chloride form, Bio-Rad, Hercules, CA, USA) resin in HCl medium. Matrix elements were removed by $8 \mathrm{~mL} 6 \mathrm{~mol} / \mathrm{L} \mathrm{HCl}$, and iron was then collected by $9 \mathrm{~mL} 0.4 \mathrm{~mol} / \mathrm{L} \mathrm{HCl}$. The same column procedure was repeated to ensure complete removal of the matrices. The final iron eluate was acidified with $0.1 \mathrm{~mL} \mathrm{HNO}_{3}$. The dried sample was then dissolved in $3 \% \mathrm{HNO}_{3}$ for isotope measurements [24].

Iron isotope measurements were conducted on a Thermo-Finnigan Neptune Plus MC-ICPMS in the Isotope Geochemistry Lab, CUGB under the "medium" high-mass resolution mode. The instrument mass bias was corrected by the sample-standard bracketing method. The standard-sample sequences were repeated a minimum of four times, and the reported isotopic composition is an average of repetitive analyses. Errors were preferentially reported as 2 s.e., 95\% confidence interval after the reference [25]. The two USGS standards BCR-2 and GSP-2 were processed with the unknown samples and their analytical $\delta^{56} \mathrm{Fe}\left\{\delta^{56} \mathrm{Fe}=\left[\left({ }^{56} \mathrm{Fe} /{ }^{54} \mathrm{Fe}\right)\right.\right.$ sample $\left.\left./\left({ }^{56} \mathrm{Fe} /{ }^{54} \mathrm{Fe}\right) \mathrm{IRMM}-014-1\right] \times 1000\right\}$ values $(+0.110 \%$ o and $+0.151 \%$ ) were in good agreement with the recommended values $[24,26]$.

\section{Result}

Eighteen whole rocks (including diorites, skarn, iron ores and limestone) were analyzed for their major elements. The results are listed in Table 2. Diorites have a large span of $\mathrm{SiO}_{2}$ content (52.4-65.4 wt.\%) for the different lithologies (hornblende diorite, monzodiorite and quartz diorite). Their LOI (loss on ignition) is relatively large, ranging from 0.78 to 2.69 wt.\%. Skarn has lower $\mathrm{SiO}_{2}$, $\mathrm{Al}_{2} \mathrm{O}_{3}$ and $\mathrm{Na}_{2} \mathrm{O}$ but higher $\mathrm{MgO}, \mathrm{CaO}$ and $\mathrm{LOI}$ contents than diorites. The $\sum \mathrm{Fe}_{2} \mathrm{O}_{3}$ content of the ore is more than $62 \%$. Limestone has high $\mathrm{CaO}$ and low $\mathrm{MgO}$, which indicates that they are mainly composed of calcite but not dolomite.

Table 2. Major elements concentration of whole rocks from the Han-Xing iron skarn deposit.

\begin{tabular}{|c|c|c|c|c|c|c|c|c|c|c|c|c|c|c|}
\hline Sample & Description & $\mathrm{SiO}_{2}$ & $\mathrm{TiO}_{2}$ & $\mathrm{Al}_{2} \mathrm{O}_{3}$ & $\sum \mathrm{Fe}_{2} \mathrm{O}_{3}$ & $\mathrm{MnO}$ & $\mathrm{MgO}$ & $\mathrm{CaO}$ & $\mathrm{Na}_{2} \mathrm{O}$ & $\mathrm{K}_{2} \mathrm{O}$ & $\mathrm{P}_{2} \mathrm{O}_{5}$ & LOI & TOTAL & $\mathrm{FeO}$ \\
\hline & Fushan district & $\%$ & $\%$ & $\%$ & $\%$ & $\%$ & $\%$ & $\%$ & $\%$ & $\%$ & $\%$ & $\%$ & $\%$ & $\%$ \\
\hline FS12-01 & Quartz Diorite & 65.4 & 0.38 & 16.7 & 3.29 & 0.05 & 1.04 & 4.04 & 4.66 & 2.68 & 0.16 & 0.78 & 99.1 & 1.08 \\
\hline FS12-02 & Altered Quartz Diorite & 61.4 & 0.39 & 18.4 & 2.02 & 0.06 & 1.96 & 2.53 & 8.39 & 1.50 & 0.25 & 2.32 & 99.2 & 1.23 \\
\hline FS12-03 & Less Altered Diorite & 58.4 & 0.69 & 16.3 & 7.56 & 0.14 & 2.82 & 5.91 & 3.72 & 2.78 & 0.30 & 0.84 & 99.5 & 3.53 \\
\hline FS12-04 & Altered Diorite & 55.0 & 0.73 & 13.6 & 4.95 & 0.06 & 7.83 & 8.96 & 4.22 & 0.98 & 0.25 & 2.30 & 98.8 & 3.03 \\
\hline FS12-05 & Hornblende Diorite & 52.4 & 1.21 & 14.6 & 10.3 & 0.12 & 6.54 & 7.20 & 4.96 & 0.84 & 0.27 & 1.08 & 99.5 & 4.65 \\
\hline FS12-09 & Gt-Di Skarn & 40.2 & 0.92 & 12.3 & 8.99 & 0.23 & 16.8 & 13.3 & 1.73 & 0.94 & 0.41 & 3.14 & 98.9 & 3.99 \\
\hline \multicolumn{15}{|c|}{ Wu'an district } \\
\hline BJ0818-21 & Altered Monzodiorite & 60.3 & 0.55 & 16.9 & 2.54 & 0.07 & 3.03 & 6.05 & 8.28 & 0.22 & 0.22 & 2.16 & 100.3 & 1.67 \\
\hline BJ0818-22 & Altered Monzodiorite & 61.0 & 0.50 & 16.5 & 2.75 & 0.08 & 3.25 & 5.81 & 8.34 & 0.10 & 0.21 & 1.56 & 100.1 & 1.71 \\
\hline BJ0818-23 & Less altered Monzodiorite & 58.5 & 0.55 & 16.5 & 5.87 & 0.08 & 3.37 & 4.24 & 5.66 & 3.68 & 0.23 & 0.96 & 99.5 & 2.85 \\
\hline BJ0818-24 & Altered Monzodiorite & 60.1 & 0.56 & 16.4 & 2.59 & 0.07 & 2.86 & 5.95 & 5.86 & 3.64 & 0.25 & 1.08 & 99.3 & 1.45 \\
\hline BJ0818-25 & Altered Monzodiorite & 59.5 & 0.51 & 16.7 & 2.18 & 0.06 & 2.93 & 6.38 & 8.33 & 0.24 & 0.24 & 2.72 & 99.8 & 1.44 \\
\hline BJ0818-25P & Altered Monzodiorite & 59.6 & 0.51 & 16.7 & 2.21 & 0.06 & 2.93 & 6.38 & 8.29 & 0.22 & 0.24 & 2.66 & 99.8 & 1.44 \\
\hline BJ0818-26 & Altered Monzodiorite & 61.3 & 0.53 & 16.4 & 2.28 & 0.06 & 2.95 & 6.20 & 8.34 & 0.34 & 0.25 & 1.84 & 100.5 & 1.50 \\
\hline BJ0818-27 & Altered Monzodiorite & 60.6 & 0.52 & 16.7 & 2.34 & 0.07 & 3.05 & 7.16 & 7.48 & 0.62 & 0.25 & 1.04 & 99.8 & 1.38 \\
\hline BJ0818-28 & Epidote Skarn & 51.8 & 0.42 & 4.56 & 5.97 & 0.13 & 11.9 & 18.6 & 0.67 & 2.76 & 0.43 & 2.04 & 99.3 & 3.90 \\
\hline BJ0818-30 & Gt-Ep Skarn & 46.3 & 0.07 & 2.46 & 4.34 & 0.07 & 16.0 & 19.1 & 0.18 & 1.37 & 0.48 & 9.43 & 99.7 & 3.11 \\
\hline BJ0818-36 & Iron Ore & 21.6 & 0.04 & 0.52 & 62.0 & 0.06 & 8.29 & 6.48 & 0.08 & 0.06 & 0.06 & -1.02 & 98.1 & na \\
\hline BJ0818-50 & Limestone & 2.20 & 0.02 & 0.41 & 0.22 & 0.01 & 0.46 & 55.5 & 0.06 & 0.03 & 0.01 & 42.1 & 101.0 & na \\
\hline BJ0818-51 & Limestone & 2.50 & 0.04 & 0.80 & 0.42 & 0.02 & 2.27 & 52.2 & 0.20 & 0.09 & 0.02 & 42.1 & 100.7 & na \\
\hline
\end{tabular}

Note: samples named by FS were collected from the outcrops, and samples named by BJ were collected from the drill cores. $\sum \mathrm{Fe}_{2} \mathrm{O}_{3}$ represents the total content of iron. FeO was determined by redox titration using $\mathrm{KMnO}_{4}$ solution. BJ0818-25P represents the duplicate of sample BJ0818-25; "na" means not analyzed.

Twenty-four whole rocks (including diorites, skarn, iron ores and limestone) and twenty-five mineral separates from iron ores and skarns (including magnetite, skarn silicate minerals and sulfides) were analyzed for their Fe isotopes. The results are listed in Table 3 . The $\delta^{56}$ Fe values of whole rocks range from $-0.203 \%$ o to $+0.172 \%$. Among them, limestone has a lower $\delta^{56}$ Fe than diorites. Skarn and ores have various $\delta^{56} \mathrm{Fe}$ values which should be caused by their heterogeneous composition. The $\delta^{56} \mathrm{Fe}$ values of mineral separates range from $-0.210 \%$ o to $+0.359 \%$. Among them, sulfides host the highest $\delta^{56} \mathrm{Fe}$ values. Magnetite has limited $\delta^{56} \mathrm{Fe}$ variation $(+0.052 \%$ o to $+0.147 \%$ o). Skarn silicates have various $\delta^{56} \mathrm{Fe}$ values, which is consistent with the large variation of mineral compositions in skarn. In addition, an approximate sequence may exist, i.e., $\delta^{56} \mathrm{Fe}_{\mathrm{Ep}}>\delta^{56} \mathrm{Fe}_{\mathrm{Gt}}>\delta^{56} \mathrm{Fe}$ Di. 
Table 3. Fe isotope composition of whole rocks and mineral separates from the Han-Xing iron skarn deposit.

\begin{tabular}{|c|c|c|c|c|c|c|}
\hline Sample & Description & $\delta^{56} \mathrm{Fe}$ & $2 \mathrm{SE}$ & $\mathcal{\delta}^{57} \mathrm{Fe}$ & 2SE & $n$ \\
\hline & Bulk Samples & & & & & \\
\hline BCR-2 & Basalt Standard & 0.110 & 0.028 & 0.144 & 0.062 & 4 \\
\hline GSP-2 & Granodiorite Standard & 0.151 & 0.034 & 0.223 & 0.040 & 4 \\
\hline FS12-01 & Quartz Diorite & 0.167 & 0.028 & 0.233 & 0.062 & 4 \\
\hline FS12-02 & Altered Quartz Diorite & -0.026 & 0.028 & 0.007 & 0.065 & 4 \\
\hline FS12-03 & Less Altered Diorite & 0.082 & 0.028 & 0.161 & 0.065 & 4 \\
\hline FS12-04 & Altered Diorite & 0.051 & 0.028 & 0.097 & 0.062 & 4 \\
\hline FS12-05 & Hornblende Diorite & 0.172 & 0.028 & 0.246 & 0.062 & 4 \\
\hline FS12-06 & Garnet Skarn & 0.008 & 0.028 & 0.037 & 0.062 & 4 \\
\hline FS12-08 & Di-Gt Skarn & -0.006 & 0.028 & -0.018 & 0.062 & 4 \\
\hline FS12-09 & Gt-Di Skarn & -0.203 & 0.028 & -0.282 & 0.062 & 4 \\
\hline FS12-10 & Ep-Gt Skarn & 0.160 & 0.028 & 0.223 & 0.062 & 4 \\
\hline FS12-13 & Iron Ore & -0.037 & 0.028 & -0.007 & 0.062 & 4 \\
\hline FS12-15 & Garnet Skarn & 0.124 & 0.028 & 0.223 & 0.062 & 4 \\
\hline FS12-17 & Iron Ore & 0.167 & 0.028 & 0.223 & 0.062 & 4 \\
\hline BJ0818-21 & Altered Monzodiorite & 0.043 & 0.019 & 0.047 & 0.037 & 4 \\
\hline BJ0818-22 & Altered Monzodiorite & 0.048 & 0.019 & 0.055 & 0.037 & 4 \\
\hline BJ0818-23 & Less altered Monzodiorite & 0.166 & 0.019 & 0.261 & 0.037 & 4 \\
\hline BJ0818-24 & Altered Monzodiorite & 0.108 & 0.019 & 0.167 & 0.037 & 4 \\
\hline BJ0818-25 & Altered Monzodiorite & 0.054 & 0.019 & 0.103 & 0.037 & 4 \\
\hline BJ0818-26 & Altered Monzodiorite & 0.073 & 0.019 & 0.066 & 0.037 & 4 \\
\hline BJ0818-27 & Altered Monzodiorite & 0.086 & 0.019 & 0.126 & 0.037 & 4 \\
\hline BJ0818-28 & Epidote Skarn & 0.083 & 0.019 & 0.088 & 0.037 & 4 \\
\hline BJ0818-28P & Epidote Skarn & 0.071 & 0.019 & 0.105 & 0.037 & 4 \\
\hline BJ0818-30 & Gt-Ep Skarn & 0.058 & 0.019 & 0.087 & 0.037 & 4 \\
\hline BJ0818-36 & Iron Ore & 0.145 & 0.019 & 0.223 & 0.037 & 4 \\
\hline BJ0818-50 & Limestone & -0.157 & 0.019 & -0.238 & 0.037 & 4 \\
\hline BJ0818-51 & Limestone & 0.042 & 0.019 & 0.063 & 0.037 & 4 \\
\hline & Mineral separates & & & & & \\
\hline FS12-12 & Magnetite & 0.088 & 0.023 & 0.131 & 0.053 & 6 \\
\hline FS12-13 & Magnetite & 0.052 & 0.023 & 0.097 & 0.053 & 6 \\
\hline FS12-14 & Magnetite & 0.091 & 0.023 & 0.145 & 0.053 & 6 \\
\hline FS12-14 & Magnetite & 0.071 & 0.028 & 0.055 & 0.065 & 4 \\
\hline FS12-16 & Magnetite & 0.105 & 0.028 & 0.149 & 0.065 & 4 \\
\hline FS12-17 & Magnetite & 0.147 & 0.028 & 0.209 & 0.065 & 4 \\
\hline FS12-06 & Pyrite & 0.359 & 0.023 & 0.542 & 0.053 & 6 \\
\hline FS12-13 & Pyrite & 0.293 & 0.023 & 0.441 & 0.053 & 6 \\
\hline FS12-14 & Pyrite & 0.293 & 0.028 & 0.423 & 0.065 & 4 \\
\hline FS12-16 & Pyrite & 0.222 & 0.028 & 0.326 & 0.065 & 4 \\
\hline FS12-05 & Amphibole & 0.094 & 0.023 & 0.140 & 0.053 & 6 \\
\hline FS12-06 & Garnet & 0.105 & 0.025 & 0.130 & 0.058 & 5 \\
\hline FS12-08 & Garnet & 0.152 & 0.023 & 0.222 & 0.053 & 6 \\
\hline FS12-10 & Garnet & 0.158 & 0.023 & 0.230 & 0.053 & 6 \\
\hline FS12-08 & Diopside & -0.028 & 0.023 & -0.032 & 0.053 & 6 \\
\hline FS12-09 & Diopside & -0.210 & 0.023 & -0.317 & 0.053 & 6 \\
\hline FS12-12 & Diopside & -0.177 & 0.023 & -0.262 & 0.053 & 6 \\
\hline FS12-08 & Epidote & 0.218 & 0.023 & 0.343 & 0.053 & 6 \\
\hline BJ0818-36 & Magnetite & 0.127 & 0.019 & 0.205 & 0.037 & 4 \\
\hline BJ0818-38 & Magnetite & 0.146 & 0.019 & 0.245 & 0.037 & 4 \\
\hline BJ0818-43 & Magnetite & 0.137 & 0.019 & 0.207 & 0.037 & 4 \\
\hline BJ0818-46 & Magnetite & 0.143 & 0.019 & 0.190 & 0.037 & 4 \\
\hline BJ0818-59 & Magnetite & 0.114 & 0.019 & 0.162 & 0.037 & 4 \\
\hline BJ0818-59 & Pyrite & 0.270 & 0.019 & 0.365 & 0.037 & 4 \\
\hline BJ0818-59P & Pyrite & 0.273 & 0.025 & 0.408 & 0.065 & 4 \\
\hline BJ0818-59 & Pyrrhotite & 0.242 & 0.025 & 0.363 & 0.065 & 4 \\
\hline
\end{tabular}

Note: BJ0818-28P represents the duplicate of sample BJ0818-28. "SE" is the standard error; " $n$ " is the number of repeat.

\section{Discussion}

\subsection{Fe Leached from the Diorites during the Hydrothermal Alteration}

The large variation in LOI (0.78-2.69 wt.\%) of diorites indicates that they underwent various degrees of hydrothermal alteration, consistent with the petrological observation mentioned above. 
As for the altered diorites with the same lithology, the more intensively altered samples (with higher LOI) are usually correlated with lower $\sum \mathrm{Fe}_{2} \mathrm{O}_{3}\left(\sum \mathrm{Fe}_{2} \mathrm{O}_{3}=\mathrm{Fe}_{2} \mathrm{O}_{3}+1.1 \times \mathrm{FeO}\right)$ contents (Figure $3 \mathrm{~A}$ and Table 2), which indicates that iron has been leached from diorites during hydrothermal alteration. $\mathrm{Fe}^{3+}$ and $\mathrm{Ti}^{4+}$ have similar charges and ionic radii, so the iron content and titanium content generally show similar trends of variation in magmatic series [27]. In the $\sum \mathrm{Fe}_{2} \mathrm{O}_{3}$ vs. $\mathrm{TiO}_{2}$ diagram (Figure 3B), there is a clear linear positive correlation $\left(R^{2}=0.924\right)$ between $\sum \mathrm{Fe}_{2} \mathrm{O}_{3}$ and $\mathrm{TiO}_{2}$ for the fresh or less altered intrusive rocks in different lithologies. However, during hydrothermal alteration, iron is more readily mobilized than titanium [28,29]. As showing in Figure 3B, the $\sum \mathrm{Fe}_{2} \mathrm{O}_{3}$ content of diorites decreased, while their $\mathrm{TiO}_{2}$ contents were almost unchanged during the hydrothermal alteration (Figure 3B). Therefore, the $\sum \mathrm{Fe}_{2} \mathrm{O}_{3} / \mathrm{TiO}_{2}$ ratio is a useful proxy for constraining the possible mobilization and transport of iron among different igneous rocks during the hydrothermal process $[28,29]$. Based on the petrological observations and major elements results, here diorites with LOI lower than $1.1 \mathrm{wt} . \%$ and $\sum \mathrm{Fe}_{2} \mathrm{O}_{3} / \mathrm{TiO}_{2}$ ratios higher than 8.5 are regarded as fresh or less altered diorites or, conversely, regarded as intensively altered diorites. By comparing the $\sum \mathrm{Fe}_{2} \mathrm{O}_{3} / \mathrm{TiO}_{2}$ ratios of fresh or less altered diorites with those of intensively altered diorites, as much as $60 \%$ iron can be extracted during the leaching process. This indicates that leaching of diorites could provide a large quantity of iron for the Han-Xing skarn deposit. Compared with the diorites, limestone has a very low $\sum \mathrm{Fe}_{2} \mathrm{O}_{3}$ content, so its contribution of iron is insignificant.
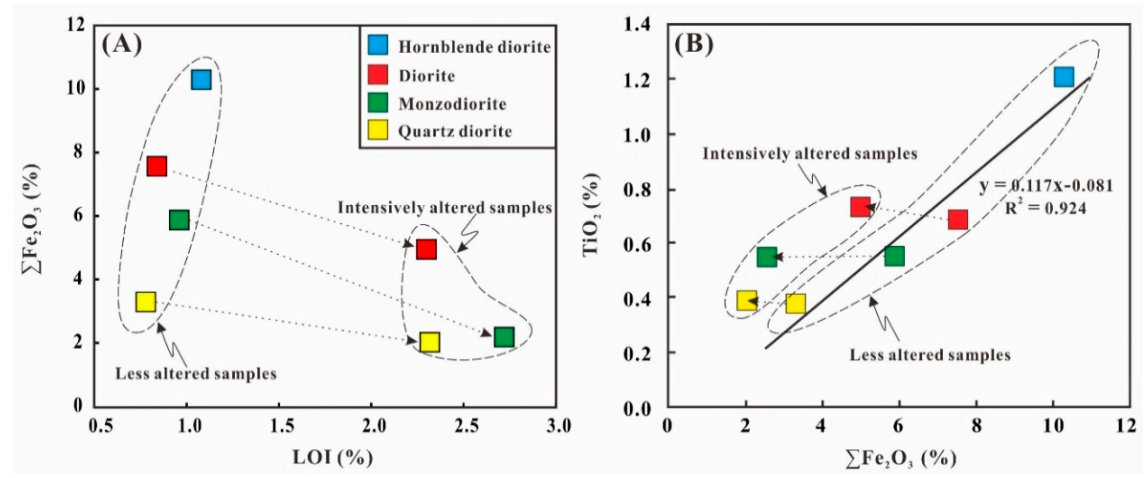

Figure 3. (A) $\sum \mathrm{Fe}_{2} \mathrm{O}_{3}$ vs. loss on ignition (LOI) diagram of intrusive rocks with different lithologies, especially for the less altered and intensively altered samples. (B) $\sum \mathrm{Fe}_{2} \mathrm{O}_{3} \mathrm{vs}$. $\mathrm{TiO}_{2}$ diagram of intrusive rocks with different lithologies, especially for the less altered and intensively altered samples.

\subsection{Fe Isotopic Variation of Whole Rocks and Mineral Separates}

Overall, the ${ }^{56} \mathrm{Fe}$ values of whole rocks and mineral separates from the Han-Xing iron skarn deposit vary from $-0.210 \%$ o to $+0.359 \%$ o (Figure 4 and Table 3 ). Diorites display a large range of variation in $\delta^{56} \mathrm{Fe}$ values $(-0.026 \%$ o to $+0.172 \%$ o), indicating Fe isotope fractionation during hydrothermal alteration. Among them, the fresh and less altered diorites host the heaviest Fe isotopic compositions, which are significantly heavier than the mean mafic earth defined in the reference [30] but consistent with the granitic rocks [31]. Limestone samples host the lightest Fe isotopic compositions. Skarn samples display a large variation in $\delta^{56} \mathrm{Fe}$ values $(-0.203 \%$ o to $+0.160 \%$ o) (Table 3$)$, which can be ascribed to the complex mineral compositions and the heterogeneous distribution of minerals. In skarn minerals, diopside hosts the lowest $\delta^{56} \mathrm{Fe}$ values $\left(-0.210 \%\right.$ o to $-0.028 \%$ o); garnet has moderate $\delta^{56} \mathrm{Fe}$ values $(+0.105 \%$ o to $+0.158 \%$ o $)$; and epidote has the highest $\delta^{56} \mathrm{Fe}$ value $(+0.218 \%$ o). In metallic minerals, magnetite has a narrow range of $\delta^{56} \mathrm{Fe}$ values $(+0.052 \%$ o to $+0.147 \%$ o) (Table 3$)$, which excludes the possibility of kinetic fractionation and indicates an Fe isotopic equilibrium between magnetite and the ore-forming fluid. Heavy Fe isotope enrichment is the most significant feature of sulfides $(+0.222 \%$ o to $+0.359 \%$ o), which may be ascribed to the higher covalence of iron chemical bonds in pyrite than that in silicates or oxides [32,33]. 


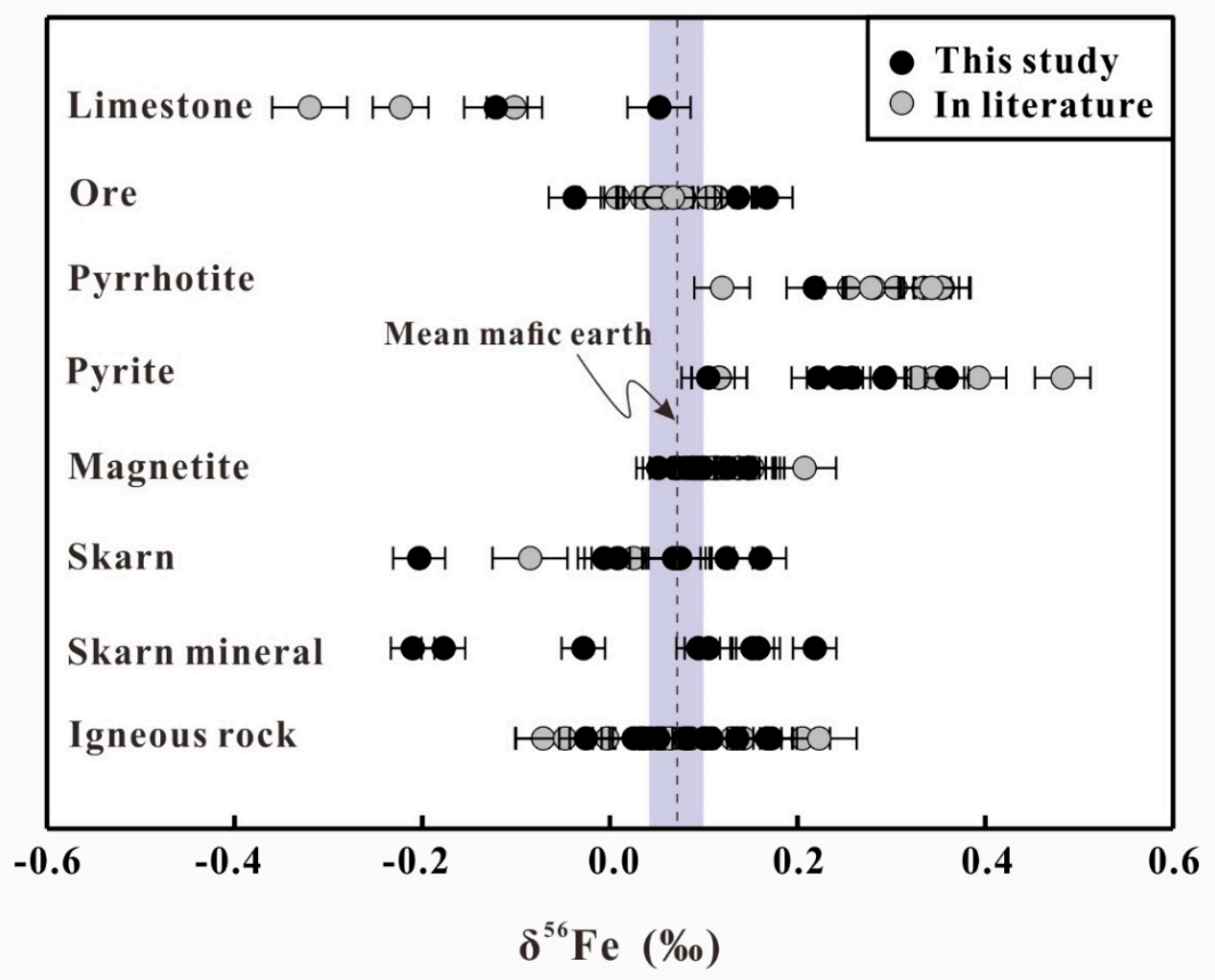

Figure 4. $\delta^{56} \mathrm{Fe}$ of whole rocks and mineral separates from the Han-Xing Fe skarn deposit. Data from this study are shown by black circles. Data from published literature are shown by gray circles [12,34]. Skarn minerals, magnetite and sulfides are picked from skarn and ores. The shaded area corresponds to the Fe isotopic composition $(0.07 \pm 0.03)$ of the mean mafic earth defined in Literature [30]. Error bars indicate $95 \%$ confidence interval (CI) of the mean.

Theoretical Fe isotopic fractionation between minerals is a function of temperature. That is to say, if isotopic equilibrium is achieved between minerals during precipitation, then any pair of minerals could be used to calculate the temperature of their formation. For skarn deposits, silicate minerals (e.g., garnet and diopside), iron oxides (e.g., magnetite and hematite) and sulfides (e.g., pyrite and pyrrhotite) are formed in different stages under different temperatures. Thus, it is not proper to use the mineral pairs chosen from different stages to calculate their forming temperature. Here, we tried to use the iron isotopes of pyrite and pyrrhotite to calculate their forming temperature, while the calculated result shows that the two minerals do not attain iron isotope equilibrium.

\subsection{Fe Isotopes Fractionation of Diorites during the Hydrothermal Alteration}

A good correlation between $\delta^{56} \mathrm{Fe}$ and $\sum \mathrm{Fe}_{2} \mathrm{O}_{3} / \mathrm{TiO}_{2}$ ratios of diorites from the Han-Xing deposit was observed (Figure 5A), which demonstrates that Fe isotopes fractionated during the hydrothermal alteration of diorites. The low $\sum \mathrm{Fe}_{2} \mathrm{O}_{3} / \mathrm{TiO}_{2}$ ratio represents a high degree of alteration with a substantial loss of iron. Therefore, the positive correlation between $\delta^{56} \mathrm{Fe}$ and $\sum \mathrm{Fe}_{2} \mathrm{O}_{3} / \mathrm{TiO}_{2}$ indicates that $\mathrm{Fe}$ isotopes of diorites evolve towards to the light Fe isotope enrichment, i.e., heavy Fe isotopes are preferentially leached from diorites during hydrothermal alteration. 

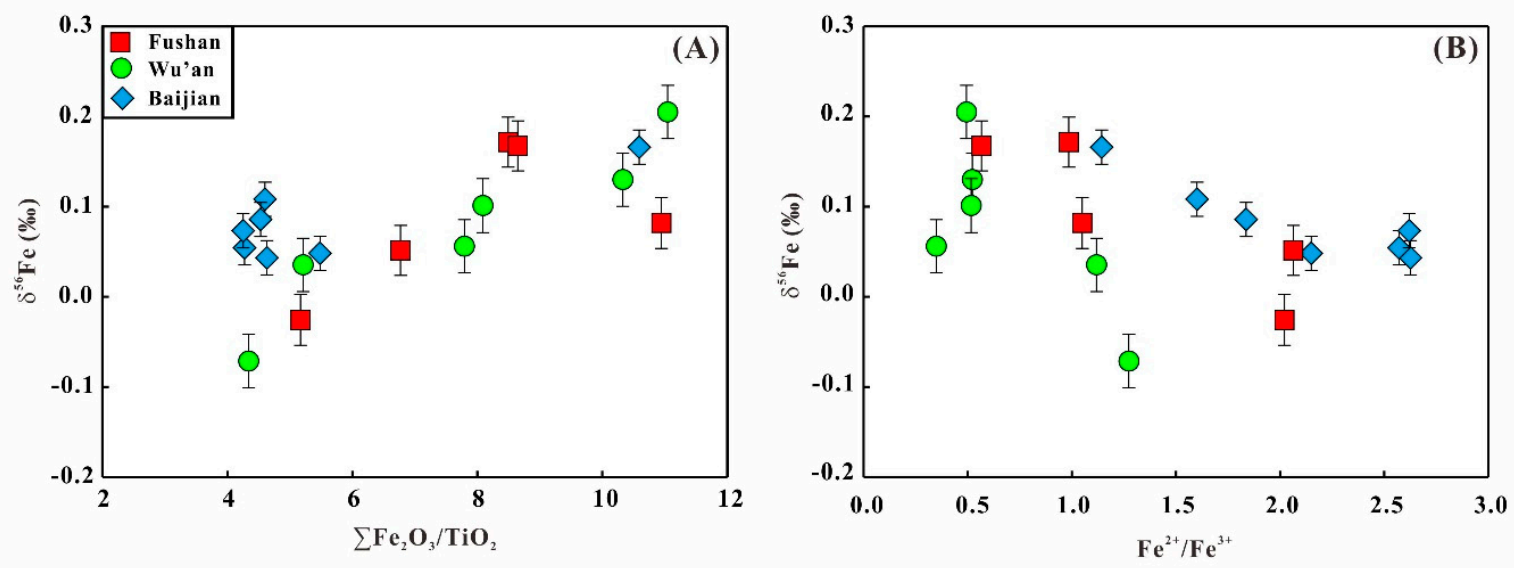

Figure 5. (A) Variations of $\delta^{56} \mathrm{Fe}$ values as a function of $\sum \mathrm{Fe}_{2} \mathrm{O}_{3} / \mathrm{TiO}_{2}$ ratios in diorites from the Han-Xing Fe skarn deposit. (B) Variations of $\delta^{56} \mathrm{Fe}$ values as a function of $\mathrm{Fe}^{2+} / \mathrm{Fe}^{3+}$ ratios in diorites from the Han-Xing Fe skarn deposit. Data of Wu'an are from the reference [12]. Error bars indicate $95 \%$ $\mathrm{CI}$ of the mean.

The $\delta^{56} \mathrm{Fe}$ values of altered diorites decrease with their $\mathrm{Fe}^{2+} / \mathrm{Fe}^{3+}$ ratios (Figures $5 \mathrm{~B}$ and 6 ), especially for the diorites with the same lithology, which hints that valence states of iron should be the main factor controlling the Fe isotopic fractionation in this process. As noted before, during hydrothermal alteration, hornblende is replaced by the diopside, biotite, albite and magnetite (Figure 2C,E), followed by the dissolution of magnetite from the diorites (Figure 2B,D,F). Since hornblende and magnetite are enriched in $\mathrm{Fe}^{3+}$ while the altered residues (e.g., diopside and biotite) are enriched in $\mathrm{Fe}^{2+}$, the $\mathrm{Fe}^{2+} / \mathrm{Fe}^{3+}$ ratios of altered diorites increase with the intensity of the hydrothermal alteration (Table 4). Furthermore, $\mathrm{Fe}^{3+}$ compounds are usually enriched in heavy Fe isotopes than $\mathrm{Fe}^{2+}$-bearing species [32,35], which explains why the Fe isotopic composition of diorites became light during hydrothermal alteration.

If we assume that iron was leached from diorites following Rayleigh fractionation, the equation $\left(1000+\delta^{56} \mathrm{Fe}_{\mathrm{A}}\right) /\left(1000+\delta^{56} \mathrm{Fe}_{\mathrm{i}}\right)=\mathrm{F}\left(\alpha_{\mathrm{B}-\mathrm{A}}-1\right)$ can be applied, where A refers to the altered diorite as the residual phase, $\mathrm{B}$ refers to the iron leached from the diorites, $\mathrm{i}$ refers to the initial $\delta^{56} \mathrm{Fe}$ values and $F\left(F=\left(\sum \mathrm{Fe}_{2} \mathrm{O}_{3} / \mathrm{TiO}_{2}\right) \mathrm{A} /\left(\sum \mathrm{Fe}_{2} \mathrm{O}_{3} / \mathrm{TiO}_{2}\right)_{\mathrm{i}}\right)$ refers to the proportion of iron in the altered diorites to the initial content. In this present case, $\mathrm{i}$ is represented by fresh or less altered diorites. The fractionation factor between leached iron and altered residues is calculated. $\alpha_{B-A}$ varies from 1.00006 to 1.00043 (Table 4 and Figure 7) (except one data of 1.00112) with an average of 1.00020, which is consistent with the iron isotope fractionation factor between magnetite and Fe silicates $(0.2 \%$ o to $0.25 \%$ o at $700^{\circ} \mathrm{C}$ ) [36,37]. Thus, iron isotope fractionation during hydrothermal alteration may be dominantly controlled by the dissolution of magnetite from diorites. 


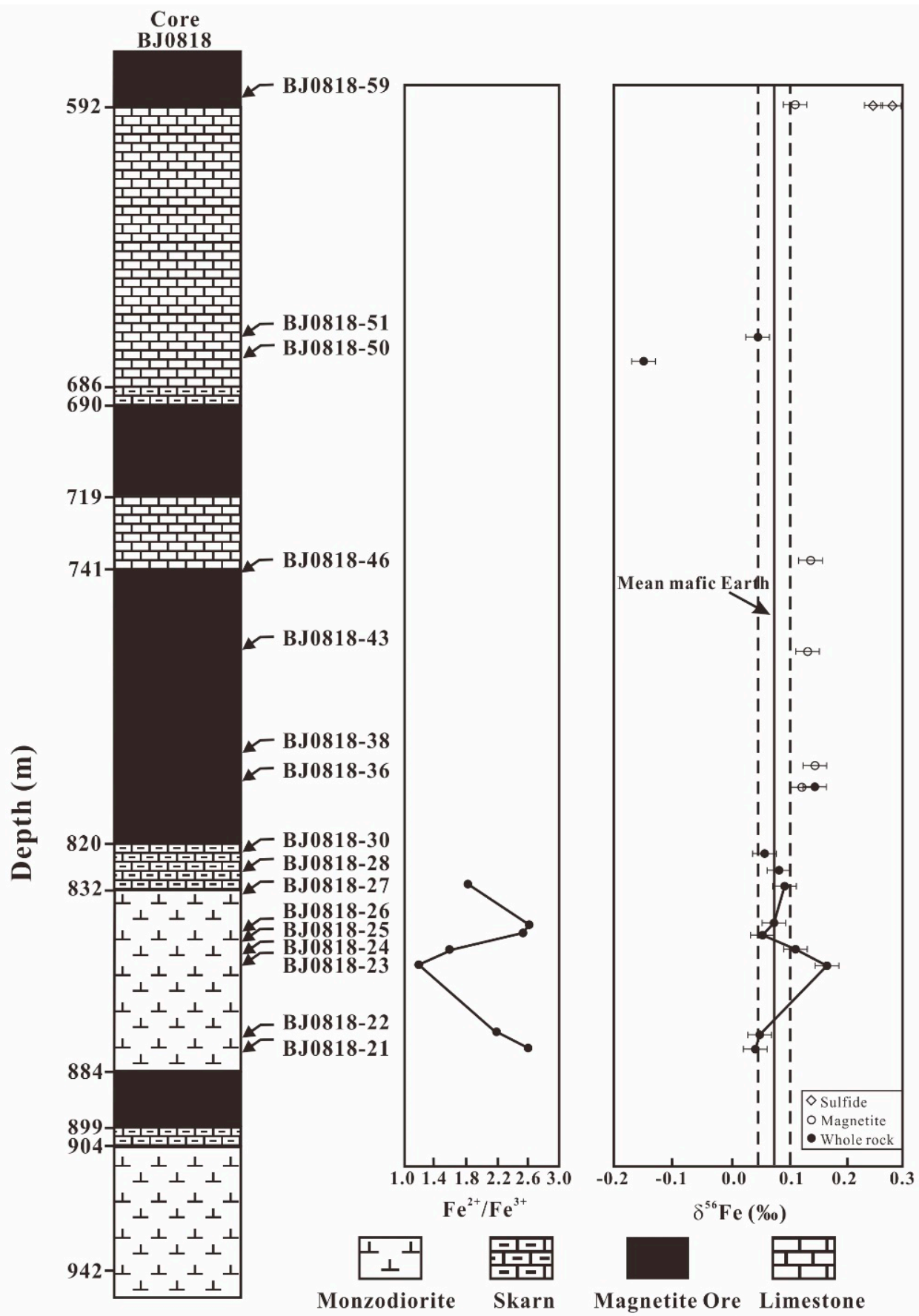

Figure 6. A synopsis of the magmatic-stratigraphic column of drill core samples BJ0818 with zonal divisions, stratigraphic variations of $\mathrm{Fe}^{2+} / \mathrm{Fe}^{3+}$ ratios of diorites and $\delta^{56} \mathrm{Fe}$ values of whole rocks, magnetite and sulfides. The solid line represents the $\delta^{56} \mathrm{Fe}$ value of the mean mafic earth. The dashed line represents the $\delta^{56} \mathrm{Fe}$ value of less altered diorite. Diorites show a clear inverse trend between their $\mathrm{Fe}^{2+} / \mathrm{Fe}^{3+}$ ratios and $\delta^{56} \mathrm{Fe}$ values. Except for the late-stage pyrite, all the rocks and minerals have lower $\delta^{56} \mathrm{Fe}$ values than the less altered diorite. Error bars indicate $95 \% \mathrm{CI}$ of the mean. 
Table 4. Selected major elements and Fe isotope composition of altered plutonic rocks from the Han-Xing iron skarn deposit.

\begin{tabular}{|c|c|c|c|c|c|c|c|c|c|c|c|c|}
\hline Sample & Description & $\sum \mathrm{Fe}_{2} \mathrm{O}_{3}$ & $\mathrm{FeO}$ & $\mathrm{TiO}_{2}$ & $\mathrm{Fe}^{2+} / \mathrm{Fe}^{3+}$ & $\sum \mathrm{Fe}_{2} \mathrm{O}_{3} / \mathrm{TiO}_{2}$ & $\mathcal{\delta}^{56} \mathrm{Fe}$ & $2 \mathrm{SE}$ & LOI & $F$ & $\alpha_{\text {B-A }}$ & $\delta^{56} \mathrm{Fe}_{\text {Leached }}$ \\
\hline FS12-01 & Quartz Diorite & 3.29 & 1.08 & 0.38 & 0.57 & 8.66 & 0.167 & 0.028 & 0.78 & 1.000 & & \\
\hline FS12-02 & $\begin{array}{l}\text { Altered } \\
\text { Quartz Diorite }\end{array}$ & 2.02 & 1.23 & 0.39 & 2.02 & 5.18 & -0.026 & 0.028 & 2.32 & 0.598 & 1.00038 & 0.455 \\
\hline FS12-03 & $\begin{array}{l}\text { Less Altered } \\
\text { Diorite }\end{array}$ & 7.56 & 3.53 & 0.69 & 1.05 & 11.0 & 0.082 & 0.028 & 0.84 & 1.000 & & \\
\hline FS12-04 & $\begin{array}{l}\text { Altered } \\
\text { Diorite }\end{array}$ & 4.95 & 3.03 & 0.73 & 2.07 & 6.78 & 0.051 & 0.028 & 2.30 & 0.619 & 1.00006 & 0.131 \\
\hline FS12-05 & $\begin{array}{l}\text { Hornblende } \\
\text { Diorite }\end{array}$ & 10.3 & 4.65 & 1.21 & 0.99 & 8.50 & 0.172 & 0.028 & 1.08 & 1.000 & & \\
\hline BJ0818-21 & $\begin{array}{l}\text { Altered } \\
\text { Monzodiorite }\end{array}$ & 2.54 & 1.67 & 0.55 & 2.63 & 4.64 & 0.043 & 0.019 & 2.16 & 0.438 & 1.00015 & 0.262 \\
\hline BJ0818-22 & $\begin{array}{l}\text { Altered } \\
\text { Monzodiorite }\end{array}$ & 2.75 & 1.71 & 0.50 & 2.15 & 5.49 & 0.048 & 0.019 & 1.56 & 0.518 & 1.00018 & 0.293 \\
\hline BJ0818-23 & $\begin{array}{l}\text { Less altered } \\
\text { Monzodiorite }\end{array}$ & 5.87 & 2.85 & 0.55 & 1.15 & 10.6 & 0.166 & 0.019 & 0.96 & 1.000 & & \\
\hline BJ0818-24 & $\begin{array}{l}\text { Altered } \\
\text { Monzodiorite }\end{array}$ & 2.59 & 1.45 & 0.56 & 1.60 & 4.61 & 0.108 & 0.019 & 1.08 & 0.435 & 1.00007 & 0.210 \\
\hline BJ0818-25 & $\begin{array}{l}\text { Altered } \\
\text { Monzodiorite }\end{array}$ & 2.20 & 1.44 & 0.51 & 2.57 & 4.29 & 0.054 & 0.019 & 2.72 & 0.404 & 1.00012 & 0.242 \\
\hline BJ0818-26 & $\begin{array}{l}\text { Altered } \\
\text { Monzodiorite }\end{array}$ & 2.28 & 1.50 & 0.53 & 2.62 & 4.26 & 0.073 & 0.019 & 1.84 & 0.402 & 1.00010 & 0.228 \\
\hline BJ0818-27 & $\begin{array}{l}\text { Altered } \\
\text { Monzodiorite }\end{array}$ & 2.34 & 1.38 & 0.52 & 1.84 & 4.54 & 0.086 & 0.019 & 1.04 & 0.428 & 1.00009 & 0.226 \\
\hline WA12-07 & $\begin{array}{l}\text { Altered } \\
\text { Monzodiorite }\end{array}$ & 6.72 & 2.10 & 0.65 & 0.52 & 10.3 & 0.130 & 0.030 & 0.68 & 0.935 & 1.00112 & 1.285 \\
\hline WA12-08 & $\begin{array}{l}\text { Altered } \\
\text { Monzodiorite }\end{array}$ & 4.94 & 1.54 & 0.61 & 0.52 & 8.10 & 0.101 & 0.030 & 1.90 & 0.732 & 1.00033 & 0.489 \\
\hline WA12-13 & $\begin{array}{l}\text { Altered } \\
\text { Monzodiorite }\end{array}$ & 3.29 & 1.58 & 0.63 & 1.12 & 5.22 & 0.035 & 0.030 & 3.89 & 0.472 & 1.00023 & 0.357 \\
\hline WA12-14 & $\begin{array}{l}\text { Less altered } \\
\text { Monzodiorite }\end{array}$ & 5.86 & 1.77 & 0.53 & 0.50 & 11.1 & 0.205 & 0.030 & 1.08 & 1.000 & & \\
\hline WA12-23 & $\begin{array}{l}\text { Altered } \\
\text { Monzodiorite }\end{array}$ & 2.48 & 1.26 & 0.57 & 1.28 & 4.35 & -0.071 & 0.030 & 2.98 & 0.394 & 1.00030 & 0.384 \\
\hline WA12-31 & $\begin{array}{l}\text { Altered } \\
\text { Monzodiorite }\end{array}$ & 4.72 & 1.12 & 0.60 & 0.35 & 7.80 & 0.056 & 0.030 & 1.92 & 0.706 & 1.00043 & 0.562 \\
\hline
\end{tabular}

Note: A represents the iron in the residual altered diorite, and B represents the iron leached from the diorite, $\delta^{56} \mathrm{Fe}_{\text {Leached }}$ represents the Fe isotopic composition of leached iron from diorite during hydrothermal alteration. Data named by WA are from the reference [12].

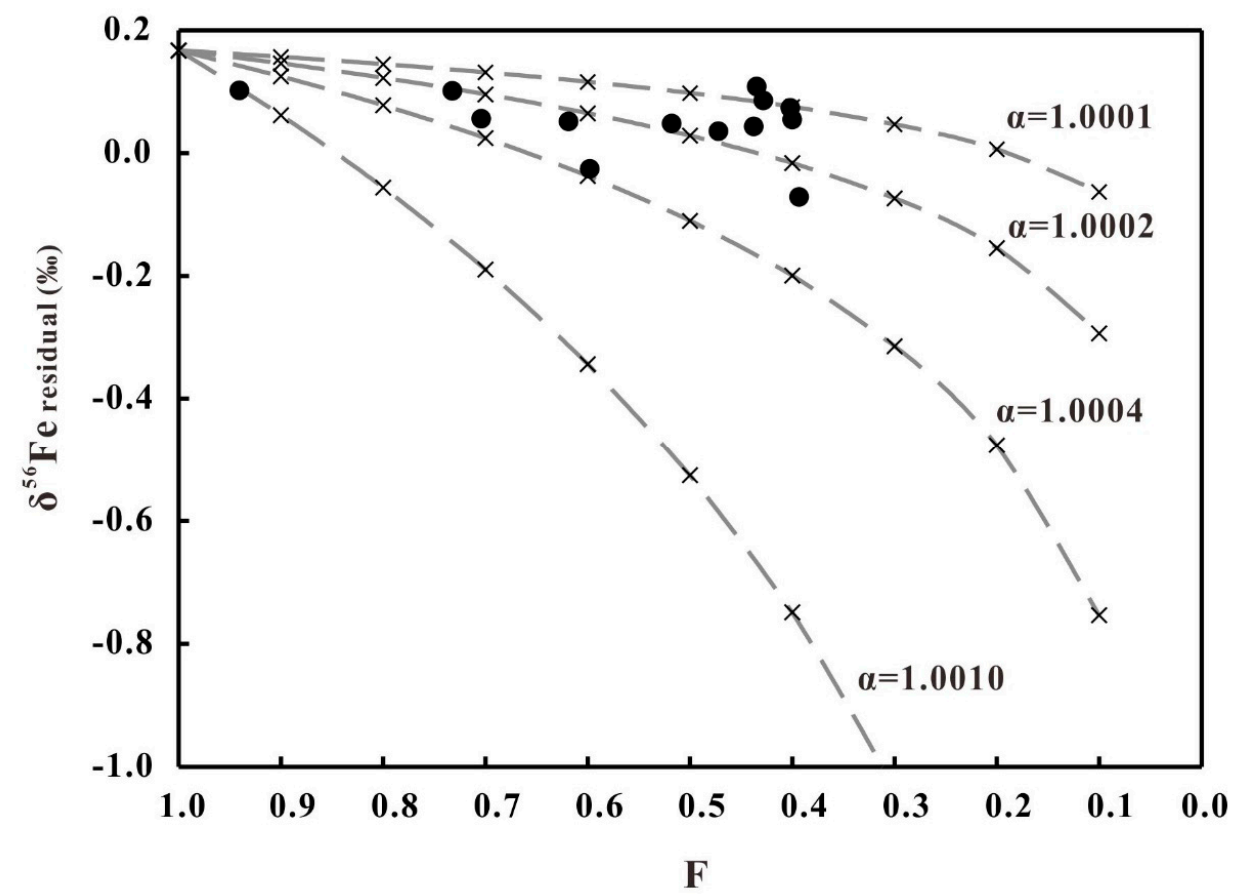

Figure 7. Rayleigh fractionation of Fe isotopes in diorites during hydrothermal alteration in the Han-Xing Fe skarn deposits. 
However, the $\mathrm{Fe}^{3+}$ is highly insoluble in aqueous solutions, e.g., [38,39], so it cannot be easily ascribed to the leaching of $\mathrm{Fe}^{3+}$ from diorites. The simplest explanation is that reduced and isotopically light fluid derived from another source altered the diorites to varying degrees, causing the dissolution of magnetite and precipitation of isotopically light phases. During this process, the isotopically light fluid interacted with the isotopically heavy rocks, leading the heavy Fe isotopes to be preferentially leached from the diorites.

\subsection{Iron Sources of the Han-Xing Fe Skarn Deposit}

Major elements results demonstrate that plenty of iron can be leached from the diorites during hydrothermal alteration. As discussed above, heavy Fe isotopes are preferentially leached from diorites, which means that the leached iron should be Fe isotopically heavier than the fresh diorite. If the leached iron contributes to the main iron source of the ore-forming fluid, then the minerals formed from the ore-forming fluid should be characterized by a heavier Fe isotope than that of the fresh diorite (or less altered diorite). However, our data show that except for the pyrite, all the rocks and minerals formed in the skarn deposits are more enriched in light Fe isotopes relative to the fresh diorite (Figure 4 and Table 3). Therefore, other sources with light Fe isotope enrichment need to be involved to explain the light Fe isotopic compositions of ores and skarn.

Exsolution of magmatic fluids is a common phenomenon in cooling intrusive rocks [40]. Measurements of drilled fluid samples and fluid inclusions have proved that magmatic fluids can own as much as $9.3 \mathrm{wt}$.\% iron [41]. Moreover, iron-bearing species in the magmatic fluids are dominated by $\mathrm{Fe}^{2+}$-chloride complexes $\left(\mathrm{FeCl}^{+}\right.$and $\left.\mathrm{FeCl}_{2}\right)$, e.g., [38,39], therefore magmatic fluids have been speculated to be characterized by light Fe isotope enrichment relative to the host igneous rocks $[36,42]$. The $\mathrm{Fe}^{2+}$-rich magmatic fluid contributes to the formation of ferrous silicate minerals (e.g., diopside) and dissolution of magnetite, which result in an increase in $\mathrm{Fe}^{2+} / \mathrm{Fe}^{3+}$ ratios of diorites during hydrothermal alteration. More importantly, hydrogen and oxygen isotopes of fluid inclusions in diopside and garnet from the Han-Xing iron skarn deposit clearly indicate that magmatic fluid dominates the composition of ore-forming fluid [15]. Therefore, we consider magmatic fluid as the other important iron source of the Han-Xing iron skarn deposit.

\subsection{Estimation of the Relative Proportions of Iron Sources for the Han-Xing Fe Skarn Deposit}

For the Han-Xing iron skarn deposit, many researchers emphasize that the scale of altered diorite (albitization) is quite large. By using the mass balance of the iron element, their calculated content of leached iron is quite enough for forming the ore deposit (e.g., references [15,17]). However, it is hard to estimate accurately the scale of altered diorite, and the extent of alteration is not homogenous. Compared with the iron element, iron isotopes can contain more information of the iron source.

As we mentioned above, both leaching of diorites and the magmatic fluid provide the iron for the Han-Xing iron deposit. Here, we try to estimate their relative proportions for the Han-Xing iron skarn deposit using the mass balance equation of iron isotopes below:

$$
\delta^{56} \mathrm{Fe}_{\text {ore-forming fluid }}=\delta^{56} \mathrm{Fe}_{\text {leached }} \times \mathrm{f}+\delta^{56} \mathrm{Fe}_{\text {magmatic fluid }} \times(1-\mathrm{f})
$$

where $\mathrm{f}$ is the fraction of leached iron in the ore-forming fluid. In order to calculate factor $\mathrm{f}$, we need to know the Fe isotopic compositions of the ore-forming fluid, leached iron and magmatic fluid.

At equilibrium, Fe isotopic fractionation between fluid and mineral is a function of temperature. Therefore, the Fe isotopic composition of the ore-forming fluid can be calculated by the $\delta^{56} \mathrm{Fe}$ values of minerals which are equilibrated with the fluid at a specified temperature. Magnetite in ores has limited variation in $\delta^{56} \mathrm{Fe}$ values $(+0.052 \%$ o to $+0.147 \%$ o) and there is no difference between coarse-grained and fine-grained magnetite with regard to their Fe isotopic composition. Moreover, the coarse-grained magnetite has a perfect octahedral crystal shape without composition zoning [12]. Therefore, magnetite should attain isotopic equilibrium with the ore-forming fluid. Fluid inclusion work [43] in this deposit 
demonstrates that the average decrepitation temperature of magnetite is $416{ }^{\circ} \mathrm{C}$. The Fe isotopic equilibrium fractionation factor between Fe (II) aq and magnetite $10^{3} \times \ln \alpha_{\mathrm{Fe}}$ (II) aq-magnetite is $-0.205 \%$ o at $416^{\circ} \mathrm{C}$ calculated by the formula given in the reference [44]. Thus, the $\delta^{56} \mathrm{Fe}$ of magnetite will be $0.205 \%$ o greater than the ore-forming fluid from which it precipitates. Magnetite in the Han-Xing iron deposit has a mean $\delta^{56} \mathrm{Fe}$ of $0.111 \%$ o $(n=11)$; therefore, the $\delta^{56} \mathrm{Fe}$ of the ore-forming fluid should be near $-0.094 \%$.

Using the mass balance equation: $\delta^{56} \mathrm{Fe}_{\mathrm{i}} \approx \delta^{56} \mathrm{Fe}_{\text {altered diorite }} \times \mathrm{F}+\delta^{56} \mathrm{Fe}_{\text {leached }} \times(1-\mathrm{F})$, where $\delta^{56} \mathrm{Fe}_{\mathrm{i}}$ refers to initial $\delta^{56} \mathrm{Fe}$, i.e., the Fe isotopes of fresh diorite, and $\mathrm{F}\left(\mathrm{F}=\left(\sum \mathrm{Fe}_{2} \mathrm{O}_{3} / \mathrm{TiO}_{2}\right)\right.$ altered diorite $/\left(\sum \mathrm{Fe}_{2} \mathrm{O}_{3} / \mathrm{TiO}_{2}\right)$ initial $)$ refers to the fraction of iron that remained in the altered diorite. The $\delta^{56} \mathrm{Fe}$ value of leached iron from the fresh quartz diorite FS-01 to the altered quartz diorite FS-02 is calculated, which is up to $+0.455 \%$ o. Considering that the diorites have undergone different degrees of alteration, here we use the mean $\delta^{56}$ Fe value of leached iron $(+0.320 \%$ ) (excluding the data of $+1.285 \%$ o) to represent the average Fe isotopic composition of leached iron (Table 4 ).

Previous studies have proposed that exsolved fluids could remove isotopically light iron and result in heavy Fe isotopes enrichment in the silicate melt, e.g., [36,42,45]. The fresh and less altered diorites in the Han-Xing district show heavy Fe isotope enrichment, suggesting that isotopically light fluid had exsolved from the magma before the diorites formed. Considering that the $\delta^{56} \mathrm{Fe}$ of the unaltered diorites is about $0.10 \%$ o higher than that of the mean mafic earth, and a large quantity of iron would partition into the magmatic fluid as a potential source for the iron skarn deposit, e.g., [41,46], the $\delta^{56} \mathrm{Fe}$ of the magmatic fluid could not be too low. Here, we assume that the magma has the same Fe isotopic composition as the mafic earth and 1/4 iron partitions into the exsolved fluid, taking the mean $\delta^{56} \mathrm{Fe}$ values $(0.177 \%$ ) of fresh or less altered diorite as the initial diorite, then the calculated $\delta^{56} \mathrm{Fe}$ of magmatic fluid is $-0.251 \%$. This value is well consistent with the $\delta^{56} \mathrm{Fe}$ of the exsolved fluid $(-0.30 \%$ o to $+0.04 \%$ o $)$ calculated in the reference [36] and the mean $\delta^{56} \mathrm{Fe}$ of hydrothermal fluids from the mid-ocean ridge $(-0.29 \%$ and $-0.23 \%$ ) reported in the references [47] and [48], respectively.

Bring the $\delta^{56}$ Fe values of the ore-forming fluid $(-0.094 \%$ o), leached iron $(+0.320 \%$ o $)$ and magmatic fluid $(-0.251 \%$ ) into Equation (1), the calculated " $\mathrm{f}$ " is 0.275 . That is to say, iron provided by the magmatic fluid is about 2.6 times as large as the leached iron. The calculated results indicate that both the magmatic fluid and leaching rocks provide significant iron for the iron skarn deposit, while the contribution of magmatic fluid is much greater than that of the leaching process. Here, we must admit that the calculated result is based on the referred iron isotopic compositions of the three members from limited data, thus the exact ratio between the ore-forming fluid and leached iron may be in doubt.

Based on the discussion above, we propose a scenario for the origin of the Han-Xing iron skarn deposit as follows. During the late stage of magmatic evolution, $\mathrm{Fe}^{2+}$-rich magmatic fluid exsolved from the magma extracts the light Fe isotope from the melt. Subsequently, the magmatic fluid might mix with the meteoric water and groundwater but its Fe isotopic composition will not be changed because of the low iron content of these fluids (ppb level) [49]. During the hydrothermal alteration, ferrous iron-enriched and isotopically light magmatic fluid altered the diorites to various degrees, causing the dissolution of isotopically heavy phases (magnetite and amphibole) and precipitation of isotopically light phases (diopside), and leading the heavy Fe isotopes to be preferentially leached from the diorites. Since the quantity of iron from magmatic fluid is about 2.6 times as large as that from the leaching process, the Fe isotopic composition of the ore-forming fluid is dominated by the isotopically light magmatic fluid. With the changes of physicochemical conditions (such as the decrease in temperature or the increase in oxygen fugacity caused by the dissolution of gypsum in limestone), iron was deposited from the ore-forming fluid as skarn minerals and magnetite inheriting the light Fe isotopic composition.

\section{Conclusions}

Based on the observations and discussions above, the following conclusions can be drawn: 
(1) Iron, especially for the heavy Fe isotopes, is preferentially leached from the dioritic rocks during the hydrothermal alteration in the formation of the Han-Xing Fe skarn deposit.

(2) Fe isotopically light magmatic fluid contributes the major iron budget for the iron skarn deposit (2.6 times of the leached iron, based on the mass balance calculation). This result supports the hypothesis that fluid exsolution from cooling and crystallizing intrusive rocks could lead to heavy $\mathrm{Fe}$ isotope enrichment. It is worth to note that, in our studies, the intrusive rocks are hornblende diorites, monzodiorite and quartz diorites which are not highly evolved granites. Thus, an important corollary to our study is that isotopically light fluids can be exsolved not only from highly differentiated granitic magmas but also from the intermediate magmas.

(3) High $\delta^{56} \mathrm{Fe}$ values of magmatic intrusions combining the positive correlation between their $\sum \mathrm{Fe}_{2} \mathrm{O}_{3} / \mathrm{TiO}_{2}$ and $\delta^{56} \mathrm{Fe}$ could be taken as a fingerprint of exsolution or interaction with magmatic fluids, which contributes to the exploration of magmatic hydrothermal ore deposits. Actually, available data on Fe isotopes of hydrothermal ore deposits show that the associated magmatic intrusions are enriched in heavy Fe isotopes, e.g., [50,51].

Author Contributions: Conceptualization, B.Z. and H.Z.; methodology, Y.H.; resources, C.H.; writing—original draft preparation, B.Z.; writing—review and editing, B.Z., H.Z., M.S., B.S., and P.Z.; funding acquisition, H.Z. All authors have read and agreed to the published version of the manuscript.

Funding: This research was financially supported by the Natural Science Foundation of China (41688013) and the Beijing Research Institute of Uranium Geology (ST1702).

Acknowledgments: The authors would like to thank Huang Zhixin for his assistance in English polishing and the financial support in the Article Processing Charge. Furthermore, we are grateful to Xu Dingshuai and Liu Yanhong for their technical support in major element analysis. The authors would like to express gratitude towards the three anonymous reviewers whose comments improved this work.

Conflicts of Interest: The authors declare no conflict of interest.

\section{References}

1. Wilkinson, J.J. Triggers for the formation of porphyry ore deposits in magmatic arcs. Nat. Geosci. 2013, 6, 917-925. [CrossRef]

2. Hedenquist, J.W.; Lowenstern, J.B. The role of magmas in the formation of hydrothermal ore deposits. Nature 1994, 370, 519-527. [CrossRef]

3. Candela, P.A.; Holland, H.D. A mass transfer model for copper and molybdenum in magmatic hydrothermal systems: The origin of porphyry-type ore deposits. Econ. Geol. 1986, 81, 1-19. [CrossRef]

4. Rye, R.O. The carbon, hydrogen, and oxygen isotopic composition of the hydrothermal fluids responsible for the lead-zinc deposits at Providencia, Zacatecas, Mexico. Econ. Geol. 1966, 61, 1399-1427. [CrossRef]

5. Ohmoto, H. Systematics of sulfur and carbon isotopes in hydrothermal ore deposit. Econ. Geol. 1972, 67, 551-578. [CrossRef]

6. Taylor, H.P., Jr. The application of oxygen and hydrogen isotope studies to problems of hydrothermal alteration and ore deposition. Econ. Geol. 1974, 69, 843-883. [CrossRef]

7. Jia, Y.; Kerrich, R. Nitrogen isotope systematics of mesothermal lode gold deposits: Metamorphic, granitic, meteoric water, or mantle origin? Geology 1999, 27, 1051-1054. [CrossRef]

8. Meinert, L.D.; Hedenquist, J.W.; Satoh, H.; Matsuhisa, Y. Formation of anhydrous and hydrous skarn in $\mathrm{Cu}$-Au ore deposits by magmatic fluids. Econ. Geol. 2003, 98, 147-156. [CrossRef]

9. Meinert, L.D.; Dipple, G.M.; Nicolescu, T. World skarn deposit. Econ. Geol. 2005, 100, 299-336.

10. Graham, S.; Pearson, N.; Jackson, S.; Griffin, W.; O’Reilly, S.Y. Tracing Cu and Fe from source to porphyry: In situ determination of $\mathrm{Cu}$ and $\mathrm{Fe}$ isotope ratios in sulfides from the grasberg $\mathrm{Cu}-\mathrm{Au}$ deposit. Chem. Geol. 2004, 207, 147-169. [CrossRef]

11. Wang, Y.; Zhu, X.K.; Mao, J.W.; Li, Z.H.; Cheng, Y.B. Iron isotope fractionation during skarn-type metallogeny: A case study of Xinqiao Cu-S-Fe-Au deposit in the Middle-Lower Yangtze valley. Ore Geol. Rev. 2011, 43, 194-202. [CrossRef] 
12. Zhu, B.; Zhang, H.F.; Zhao, X.M.; He, Y.S. Iron isotope fractionation during skarn-type alteration: Implications for metal source in the Han-Xing iron skarn deposit. Ore Geol. Rev. 2016, 74, 139-150. [CrossRef]

13. Ohmoto, H. Stable isotope geochemistry of ore deposits. Rev. Mineral. 1986, 16, 491-559.

14. Kodera, P.; Rankinm, A.H.; Lexa, J. Evolution of fluids responsible for iron skarn mineralisation: An example from the Vyhne-Klokoc deposit, Western Carpathians, Slovakia. Mineral. Petrol. 1998, 64, 119-147. [CrossRef]

15. Zheng, J.M. The Ore-Forming Fluid and Mineralization of Skarn Fe Deposits in Handan-Xingtai Area, South Hebei. Ph.D. Thesis, China University of Geosciences, Beijing, China, 2007. (In Chinese).

16. Einaudi, M.T.; Meinert, L.D.; Newberry, R.J. Skarn deposits. In Economic Geology 75th Anniversary Volume; The Economic Geology Publishing Company Library of Congress: New Haven, CT, USA, 1981; pp. 317-391.

17. Feng, Z.Y. Comparison of iron skarn generating intrusions with barren intrusions in southern taihang mountain, China. Geosciences 1998, 1, 467-476. (In Chinese)

18. Shen, J.-F.; Santosh, M.; Li, S.-R.; Zhang, H.-F.; Yin, N.; Dong, G.-C.; Wang, Y.-J.; Ma, G.-G.; Yu, H.-J. The Beiminghe skarn iron deposit, eastern China: Geochronology, isotope geochemistry and implications for the destruction of the North China Craton. Lithos 2013, 156-159, 218-229. [CrossRef]

19. Zhai, M.G.; Santosh, M. The early Precambrian odyssey of the North China Craton: A synoptic overview. Gondwana Res. 2011, 20, 6-25. [CrossRef]

20. Chen, B.; Tian, W.; Jahn, B.M.; Chen, Z.C. Zircon SHRIMP U-Pb ages and in-situ Hf isotopic analysis for the Mesozoic intrusions in South Taihang, North China Craton: Evidence for hybridization between mantle-derived magmas and crustal components. Lithos 2008, 102, 118-137. [CrossRef]

21. Zhang, Z.; Hou, T.; Santosh, M.; Li, H.; Li, J.; Zhang, Z.; Song, X.; Wang, M. Spatio-temporal distribution and tectonic settings of the major iron deposits in China: An overview. Ore Geol. Rev. 2014, 57, 247-263. [CrossRef]

22. Zhao, G.C.; Sun, M.; Wilde, S.A.; Li, S.Z. Late Archean to Paleoproterozoic evolution of the North China Craton: Key issues revisited. Precambrian Res. 2005, 136, 177-202. [CrossRef]

23. Qian, Q.; Hermann, J. Formation of high-Mg diorites through assimilation of peridotite by monzodiorite magma at crustal depths. J. Petrol. 2010, 51, 1381-1416. [CrossRef]

24. He, Y.; Ke, S.; Teng, F.-Z.; Wang, T.; Wu, H.; Lu, Y.; Li, S. High precision iron isotope analysis of geological standards by high resolution MC-ICPMS. Geostand. Geoanal. Res. 2015, 39, 341-356. [CrossRef]

25. Dauphas, N.; Pourmand, A.; Teng, F.Z. Routine isotopic analysis of iron by HR-MC-ICPMS: How precise and how accurate? Chem. Geol. 2009, 267, 175-184. [CrossRef]

26. Craddock, P.R.; Dauphas, N. Iron isotopic compositions of geological reference materials and chondrites. Geostand. Geoanal. Res. 2011, 35, 101-123. [CrossRef]

27. Irvine, T.N.; Baragar, W.R.A. A guide to the chemical classification of the common volcanic rocks. Can. J. Earth Sci. 1971, 8, 523-547. [CrossRef]

28. Rouxel, O.; Dobbek, N.; Ludden, J.; Fouquet, Y. Iron isotope fractionation during oceanic crust alteration. Chem. Geol. 2003, 202, 155-182. [CrossRef]

29. Dauphas, N.; van Zuilen, M.; Wadhwa, M.; Davis, A.M.; Marty, B.; Janney, P.E. Clues from Fe isotope variations on the origin of early Archean BIFs from Greenland. Science 2004, 306, 2077-2080. [CrossRef]

30. Poitrasson, F.; Halliday, A.N.; Lee, D.C.; Levasseur, S.; Teutsch, N. Iron isotope differences between Earth, Moon, Mars and Vesta as possible records of contrasted accretion mechanisms. Earth Planet. Sci. Lett. 2004, 223, 253-266. [CrossRef]

31. Foden, J.; Sossi, P.A.; Wawryk, C.M. Fe isotopes and the contrasting petrogenesis of A-, I- and S-type granite. Lithos 2015, 212-215, 32-44. [CrossRef]

32. Polyakov, V.B.; Mineev, S.D. The use of Mössbauer spectroscopy in stable isotope geochemistry. Geochim. Cosmochim. Acta 2000, 64, 849-865. [CrossRef]

33. Blanchard, M.; Poitrasson, F.; Meheut, M.; Lazzeri, M.; Mauri, F.; Balan, E. Iron isotope fractionation between pyrite $\left(\mathrm{FeS}_{2}\right)$, hematite $\left(\mathrm{Fe}_{2} \mathrm{O}_{3}\right)$ and siderite $\left(\mathrm{FeCO}_{3}\right)$ : A first-principles density functional theory study. Geochim. Cosmochim. Acta 2009, 73, 6565-6578. [CrossRef]

34. Chen, Y.J.; Su, S.; He, Y.; Li, S.; Hou, J.G.; Feng, S.C.; Ke, G. Fe isotope compositions and implications on the mineralization of Xishimen iron deposit in Wuan, Hebei. Acta Petrol. Sin. 2014, 30, 3443-3454. (In Chinese)

35. Schauble, E.A.; Rossman, G.R.; Taylor, H.P., Jr. Theoretical estimates of equilibrium Fe-isotope fractionations from vibrational spectroscopy. Geochim. Cosmochim. Acta 2001, 65, 2487-2497. [CrossRef] 
36. Heimann, A.; Beard, B.L.; Johnson, C.M. The role of volatile exsolution and sub-solidus fluid/rock interactions in producing high ${ }^{56} \mathrm{Fe} /{ }^{54} \mathrm{Fe}$ ratios in siliceous igneous rocks. Geochim. Cosmochim. Acta 2008, 72, 4379-4396. [CrossRef]

37. Shahar, A.; Young, E.D.; Manning, C. Equilibrium high temperature Fe isotope fractionation between fayalite and magnetite: An experimental calibration. Earth Planet. Sci. Lett. 2008, 268, 330-338. [CrossRef]

38. Chou, I.M.; Eugster, H.P. Solubility of magnetite in supercritical chloride solutions. Am. J. Sci. 1977, 277, 1296-1314. [CrossRef]

39. Fein, J.B.; Hemley, J.J.; D'Angelo, W.M.; Komninou, A.; Svergensky, D.A. Experimental study of iron-chloride complexing in hydrothermal fluids. Geochim. Cosmochim. Acta 1992, 56, 3179-3190. [CrossRef]

40. Richards, J.P. Tectono-magmatic precursors for porphyry $\mathrm{Cu}-(\mathrm{Mo}-\mathrm{Au})$ deposit formation. Econ. Geol. 2003, 98, 1515-1533. [CrossRef]

41. Yardley, B.W.D. Metal concentrations in crustal fluids and their relationship to ore formation. Econ. Geol. 2005, 100, 613-632. [CrossRef]

42. Poitrasson, F.; Freydier, R. Heavy iron isotope composition of granites determined by high resolution MC-ICP-MS. Chem. Geol. 2005, 222, 132-147. [CrossRef]

43. Zhang, B.M.; Zhao, G.L.; Ma, G.X. The Metallogenic Series and Models of the Main Metallogenic Zones in Hebei Province; Petroleum Industry Press: Beijing, China, 1996; pp. 1-273. (In Chinese)

44. Frierdich, A.J.; Beard, B.L.; Scherer, M.M.; Johnson, C.L. Determination of the Fe (II) aq-magnetite equilibrium iron isotope fractionation factor using the three-isotope method and a multi-direction approach to equilibrium. Earth Planet. Sci. Lett. 2014, 391, 77-86. [CrossRef]

45. Telus, M.; Dauphas, N.; Moynier, F.; Tissot, F.L.H.; Teng, F.-Z.; Nabelek, P.I.; Graddock, P.R.; Groat, L.A. Iron, zinc, magnesium and uranium isotopic fractionation during continental crust differentiation: The tale from migmatites, granitoids and pegmatites. Geochim. Cosmochim. Acta 2012, 97, 247-265. [CrossRef]

46. Baker, T.; van Achterberg, E.; Ryan, C.G.; Lang, J.R. Composition and evolution of ore fluids in a magmatic-hydrothermal skarn deposit. Geology 2004, 32, 117-120. [CrossRef]

47. Severmann, S.; Johnson, C.M.; Beard, B.L.; German, C.R.; Edmonds, H.N.; Chiba, H.; Green, D.R.H. The effect of plume processes on the Fe isotope composition of hydrothermally derived Fe in the deep ocean as inferred from the Rainbow vent site, Mid-Atlantic Ridge, 36² $14^{\prime}$ N. Earth Planet. Sci. Lett. 2004, 225, 63-76. [CrossRef]

48. Bennett, S.A.; Rouxel, O.; Schmidt, K.; Schönberg, D.G.; Statham, P.J.; German, C.R. Iron isotope fractionation in a buoyant hydrothermal plume, $5^{\circ} \mathrm{S}$ Mid-Atlantic Ridge. Geochim. Cosmochim. Acta 2009, 73, 5619-5634. [CrossRef]

49. Chilton, J. Water Quality Assessments-A Guide to Use of Biota, Sediments and Water in Environmental Monitoring; Chapman, D., Ed.; Great Britain at the University Press: Cambridge, UK, 1996; pp. 394-481.

50. Wawryk, C.M.; Foden, J.D. Fe-isotope fractionation in magmatic-hydrothermal mineral deposits: A case study from the Renison Sn-W deposit, Tasmania. Geochim. Cosmochim. Acta 2014, 150, 285-298. [CrossRef]

51. Wang, Y.; Zhu, X.K.; Cheng, Y.B. Fe isotope behaviors during sulfide-dominated skarn type mineralization. J. Asian Earth Sci. 2015, 103, 374-392. [CrossRef]

Publisher's Note: MDPI stays neutral with regard to jurisdictional claims in published maps and institutional affiliations.

(C) 2020 by the authors. Licensee MDPI, Basel, Switzerland. This article is an open access article distributed under the terms and conditions of the Creative Commons Attribution (CC BY) license (http://creativecommons.org/licenses/by/4.0/). 